\title{
Comparison Study of Swimmers Start's Reaction Time in Sindelfingen International Championship in Germany as a guide for training program
}

\author{
Dr. Mahmoud Medhat Mahmoud Arif ${ }^{(*)}$
}

\section{Introduction and research problem:}

Swimming sport is characterized by special competition due to the diversity of its performance methods and because it is in the fore position in international and Olympics competitions, so it requires to be built on scientific basis in order achieve Egyptian, Arab best levels and access global levels.

Swimming like any other sports require making the utmost effort, supported with numerous and overlapping factors, including appropriate training for efficiency type, swimmer physical and functional ability to sound performance (good technique), as well as using training methods and tools that help to raise performance level, within the important swimming requirements is the motor response speed from high start (start reaction time) because it is works to change body position from stillness to movement during starting after hearing the start signal, motor response speed determine race results at convergence levels, especially in short distances races.

Abdel-Fattah(1997, pp178) points out that speed exercises require some neural activity. Within speed range what so-called "reaction speed" which is the period between the stimuli and response. Reaction speed is considered an important factor in sport; which generally help to avoid using non required muscles to perform a movement. It also indicates the extent of athlete's neuromuscular coordination. Speed is associated with nervous system and muscles' fibers effect. Speed training aims to raise nervous system and muscle efficiency as well as some other factors.

Abdel-Hamid, and Hassanein (1997, p77) point that speed means the individual's ability to perform repetitive movements of one kind in the lowest possible time such as swimming, one of speed types is reaction speed; such as start in swimming.

Abdel-Fattah and Sayed (1993, pp178-179) indicate that speed is the ability to move body limbs, part of body leverages, or whole body in the lowest possible time. Speed is an independent direct factor, as in start reaction speed when responding to start signal in swimming.

Mokhtar (1990, p89) states that reaction speed is the neuromuscular system's ability to complete the response reaction in the lowest possible time, and that reaction speed varies from player to another.

Abdel-Hamid, and Hassanein (2001, p57) indicates that reaction speed is the time period between the emergence of certain stimuli and the motor response for this stimuli. These have a major importance in determining the appropriate response to different stimuli, whether simple or complex.

Mageed (1997, p533) indicates that speed element is of great importance in most of physical activities, and is the main component of short distance swimming, reaction speed is of speed types that have great importance in swimming.

Abdel-Fattah (1997. pp189-193) argues that reaction is divided to simple reaction when a stimulus is known as in swimming start and complex reaction when a stimulus is not known in advance..

Hassanein (1995, p469), indicates that the reaction speed has particular importance in the races' beginning, since player speed at race beginning have an psychological effect on other racers.

\footnotetext{
${ }^{(*)}$ Lecturer, water sports training department, Faculty of Physical Education for Men, Alexandria university
} 
Hassanein and Moafi (1998, pp75-76) indicate that reaction time is the time period between the emergence of a stimulus and beginning of motor response, while motor response time contains the time from the moment the stimulus emergence and motor response end.

Hammad (1990. P463) and Abdel-Fattah (1997, pp181) pointed out that the reaction time is the period of time between stimulus occurrence and the beginning of motor response to this stimulus, and is defined as the time that elapses between the release of the stimulus and motor responding start; reaction time is the time elapse between the stimulus emergence and motor response beginning.

Abdel-Fattah (1994, p26) argues that start is of the important factors to win in short-distance competitions

Kennefick, Maslovatand and Carlsen $(2014$, p135) indicate that movement producing the simple reaction time is separated into two time periods: the movement start time, which is thought to include preparatory processes, and the reaction time interval, which includes processes started work. Previous research has shown that excitability decreases prior to the "start signal" and increases following the "start signal"; however these two time frames have been examined independently

Majlisho (2003. pp403-405, 1993, p139) and point out that feet must be straighter and with same shoulder level and must be wrapped on the edge for stability and control, and so when swimmer bend the body, the center of gravity will move from chest bone to spine base, swimmer hold the edge with his hands from inside or outside feet and thus thighs change center of gravity and most of body weight moves forward, and with the start signal the swimmer push forward with arms and move thighs to quickly forward and push towards legs, then flight phase and entry into the water after head falling from push position.

Abdel-Fattah (1997. P33) states that back stroke start differ from those in other swimming methods where it is from within the water itself, and the most significant development for this method is that swimmer use dolphin leg strokes after push, flight and water entrance and stay underwater for longer distance up to 15 meter.

Hussein (1998, p139) points out that speed development characteristics for males between 16-18 years indicate that speed should developed and motor reaction speed should be increased, speed development means developing all motor events whether in motor or transition speed.

Garcia-Hermoso, Escalante, Arellano, Navarro, Domínguez, and Saavedra (2013) conducted a study titled "Relationship between Final Performance and Block Times with the Traditional and the New Starting Platforms with A Back Plate in International Swimming Championship 50-M and 100-M Freestyle Events "; which aimed at investigate the association between block time and final performance for each sex in 50-m and 100-m individual freestyle. Their results declare that men had shorter starting block times than women in both events (free $50 \mathrm{~m}$ $, 100 \mathrm{~m})$ and from both platforms. For 50-m event, medalists had shorter block times (1:3) than semifinalists with the old starting platforms. Block times were directly related to performance with the old starting platforms. With the new starting platforms, however, the relationship was inverse, notably in the women's 50-m event.

Thanopoulos, Rozi, Okičić, Dopsaj, Jorgić, Madić et al (2012) conducted a study aimed at determine the differences in the kinematic parameters between the grab and track starts and the differences in these two starts between genders. Their results indicated that males had significantly better results for flight time and flight distance compared with females for the grab start. In the case of the track start, the males had significantly better results for flight distance. Therefore, a conclusion that demonstrates the superiority of one of the techniques cannot be reached, so it was recommended that the coach, together with each swimmer individually, should devote some time to 
decide after some tests what type of start is better for the body type and general qualifications of the swimmer.

Beretić , Đurović, and Okičić (2012) conducted a study aimed at find the differences in kinematical parameters between different types of swimming start performance, one from a starting block with a new incline back plate platform and the other from a starting block without the back plate. Their results indicated that the start with a back plate was significantly faster than the start without a back plate on the $10 \mathrm{~m}$ sprint. Significant differences were determined for the size of the rear leg knee joint angle. It is recommended that the values in the angle of the rear knee joint at the set position in a start with the back plate could be slightly higher. As a result, the Center of Gravity should be moved forward slightly, allowing even faster reaction time, significantly shorter flight time duration without sacrificing a significant reduction in flight distance.

Mageed and Omar (2001) conducted a study aimed at finding the mechanical differences between traditional and grab starts and finding the relationship between mechanical variables in the traditional and grab starts and determine mechanical variables differ in grab start than traditional start, researchers have used descriptive approach Egypt international (12) 100, 200 and 400meters crawl swimmers were selected intentionally. Researchers concluded that compression time, flight speed, entrance speed and start distance start are the mechanical measurements that characterize both the traditional and grab starts.

Due to the vital role of reaction time as an indicator of time which swimmer consumes between start signal and start; which indicates swimmer's ability to change his body position from stillness to movement, research importance is clear as win or lose in swimming is determined by tenths of a second, and that the marginal improvement in the start-up phase can give statistically significant interest in race outcome, and due that all elements of win achievements should be trained on through training programs aim at reaction time training; which has an importance in achieving required time in the competition. Therefore, researcher, through his work as coach during the Germany International Championship (Sindelfingen), noticed significant difference in swimmers reaction time in different ages and different races distances for different swimming methods; that prompt the researcher to conduct a comparative study of swimmers reaction time in different swimming race, methods and age stages as a guide for training programs

\section{Research objective:}

The research aims at identify swimmers' start reaction time as a guide for training programs through comparing swimmers reaction between the four swimming methods, different age stages, and gender in 50, 100 , and 200 meters swimming.

\section{Research Queries:}

1- Are there statistically significant differences in swimmers' start reaction time between different age stages, the four swimming method, and boys and girls in 50 meter races?

2- Are there statistically significant differences in swimmers' start reaction time between different age stages, the four swimming method, and boys and girls in 100 meter races?

3- Are there statistically significant differences in swimmers' start reaction time between different age stages, the four swimming method, and boys and girls in 200 meter races?

\section{Research procedures:}

\section{I - Research Methodology:}

Researcher used descriptive approach as it suits the research nature. 


\section{II- Research domains}

1- Human domain: All swimmers participating in Sindelfingen International championship (13 ${ }^{\text {th }}$ World Championship) at Germany, many clubs from many (65) countries had participated in this championship including (9) clubs from Egypt, (2774) swimmers participated in this championship in different age stages divided into 5 categories as follows:

- (10-11) years stage (born in 1996-1997)

- $\quad$ (12-13) years stage (born in 1994-1995)

- (14-15) years stage (born in 1992-1993)

- (16-17) years stage (born in 1990-1991)

- General (born in 1989 and before )

2- Spatial Domain: Sindelfingen Club, Germany

3- Time-domain: from February $17^{\text {th }}$, to February $18^{\text {th }}, 2007$

III- Data collection methods: Researcher was able during attending the championship to obtain the raw data from information center in charge of championship management and results announcement as follows:

- Talking to those in charge of information and statistics center about research idea which contributed in supporting the researcher with all required data (all races times -reaction times for all simmers in all ages and swimming types - complete statement of countries and swimmers participated in the championship.

- All required data (reaction times for all simmers in all ages and swimming types) obtained through the electronic system linked to electronic watch, it is consisted of electronic board on start cube linked to the electronic board at race end place (touch board) and also linked to start signal device with the referee, when the referee gives the start signal, swimmer leave start cube, when swimmer's feet leave the cube the electric circuit separated, the time between start signal and swimmers leaving the cube is the reaction time which appear automatically on the electronic watch, with each race time, and each race final time, all this data are saved automatically on the computer operated by champion organization committee, all data were obtained from this committee, a model of reaction times is attached (appendix 1)

\section{- Results and discussions}

Table (1) Reaction time descriptive statistics per age stages (50 meter race)

\begin{tabular}{l|l|l|l|l|l}
\hline \hline Variables & Age Stage & n & Mean & Standard deviation & Maximum value \\
\hline \hline \multirow{5}{*}{ Reaction time } & Born in 96-97 & 101 & 0.66 & 0.36 & 1.17 \\
\cline { 2 - 6 } & Born in 94-95 & 313 & 0.76 & 0.24 & 1.11 \\
\cline { 2 - 6 } & Born in 92-93 & 268 & 0.80 & 0.20 & 1.09 \\
\cline { 2 - 6 } & Born in 90-91 & 206 & 0.79 & 0.18 & 1.04 \\
\cline { 2 - 6 } & General & 239 & 0.76 & 0.22 & 0.97 \\
\cline { 2 - 6 } & Total & 1127 & 0.76 & 0.23 & 1.17 \\
\hline \hline
\end{tabular}




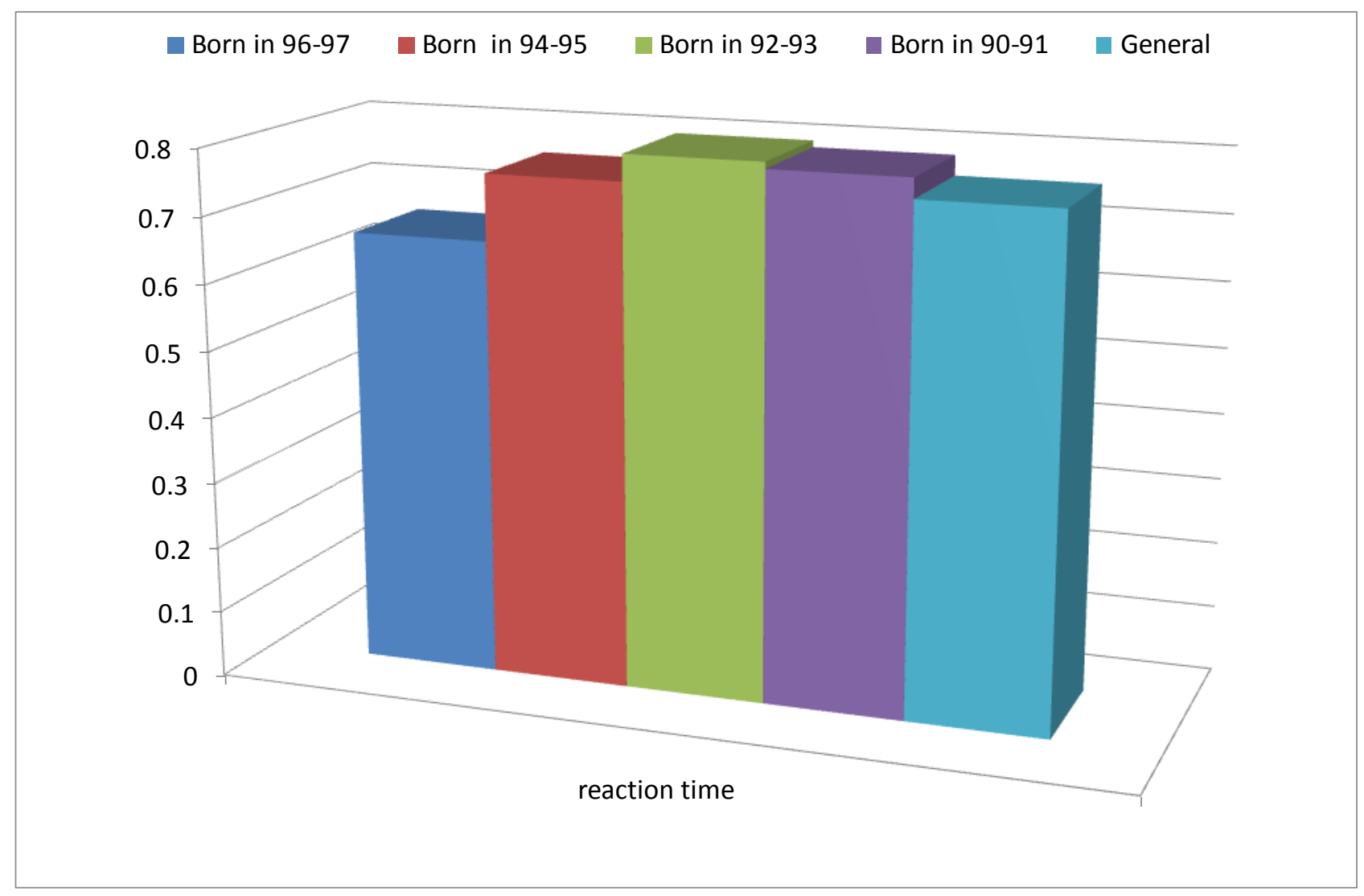

Figure (1) Reaction time per age stages (50 meter race)

Table (2)

Reaction time Differences significance between age stages (50 Meter race)

\begin{tabular}{l|l|l|l|l|l|c}
\hline \hline \multirow{2}{*}{$\begin{array}{l}\text { Statistics } \\
\text { variables }\end{array}$} & Variance source & $\begin{array}{c}\text { Squares } \\
\text { total }\end{array}$ & $\begin{array}{c}\text { degrees of } \\
\text { freedom }\end{array}$ & $\begin{array}{c}\text { Squares } \\
\text { mean }\end{array}$ & $\begin{array}{c}\text { F } \\
\text { Value }\end{array}$ & $\begin{array}{c}\text { Significance } \\
\text { Level } \\
(\mathbf{p})\end{array}$ \\
\hline \hline \multirow{2}{*}{ Reaction time } & Between age stages & 1.60 & 4 & 0.40 & & \multirow{2}{*}{$7.62 *$} \\
\cline { 2 - 5 } & Within age stages & 58.92 & 1122 & 0.05 & 0.00 \\
\cline { 2 - 5 } & Total & 60.52 & 1126 & & \\
\hline \hline
\end{tabular}

Table (2) results reveal existence of statistically significant differences between ages stages in reaction time (for 50meter race) at 0.05 level, where $\mathrm{F}$ calculated value is greater than its significant value at 0.05 level and significance level $(\mathrm{P}<0.05)$ which necessitating conducting post average test to determine these differences direction and significance . the researcher will perform LSD test at 0.05 level. 
Table (3)

LSD test at 0.05 level to determine differences significance and direction between age stages in reaction time ( for 50 meter race)

\begin{tabular}{|c|c|c|c|c|}
\hline Variables & main age stage & Sub age stage & Mean difference & Significance level \\
\hline \multirow{20}{*}{$\begin{array}{l}\text { Reaction time } \\
\text { (50 meter race) }\end{array}$} & \multirow{4}{*}{ Born in $96-97$ (D) } & Born in $94-95(\mathrm{C})$ & $-0.10447 *$ & 0.00 \\
\hline & & Born in 92-93 (B) & $-0.13806 *$ & 0.00 \\
\hline & & Born in $90-91(\mathrm{~A})$ & $-0.13578 *$ & 0.00 \\
\hline & & OFFENE & $0.09965^{*}$ & 0.00 \\
\hline & \multirow{4}{*}{ Born in $94-95(C)$} & Born in 96-97 (D) & $0.10447 *$ & 0.00 \\
\hline & & Born in 92-93 (B) & -0.03 & 0.08 \\
\hline & & Born in $90-91(\mathrm{~A})$ & -0.03 & 0.13 \\
\hline & & OFFENE & 0.00 & 0.81 \\
\hline & \multirow{4}{*}{ Born in $92-93(B)$} & Born in 96-97 (D) & $0.13806^{*}$ & 0.00 \\
\hline & & Born in $94-95(\mathrm{C})$ & 0.03 & 0.08 \\
\hline & & Born in $90-91(\mathrm{~A})$ & 0.00 & 0.91 \\
\hline & & OFFENE & 0.04 & 0.06 \\
\hline & \multirow{4}{*}{ Born in $90-91(\mathrm{~A})$} & Born in 96-97 (D) & $0.13578 *$ & 0.00 \\
\hline & & Born in $94-95(\mathrm{c})$ & 0.03 & 0.13 \\
\hline & & Born in 92-93 (B) & 0.00 & 0.91 \\
\hline & & OFFENE & 0.04 & 0.10 \\
\hline & \multirow{4}{*}{ OFFENE } & Born in 96-97 (D) & $0.09965^{*}$ & 0.00 \\
\hline & & Born in $94-95(\mathrm{C})$ & 0.00 & 0.81 \\
\hline & & Born in $92-93(\mathrm{~B})$ & -0.04 & 0.06 \\
\hline & & Born in $90-91(\mathrm{~A})$ & -0.04 & 0.10 \\
\hline
\end{tabular}

* Mean difference is significant at 0.05 level.

Positive signal means that differences in the direction of main group and negative signal means that differences in the direction of the sub-group

Table(3) results declare that that there were significant differences between born in 96-97 (D) age stage and born in 94-95 (C), born in 92-93 (B), born in 90-91 (A), and general (OFFENE) stage in favor of born in 96- 97 (D)

The same table results also declare that the differences between other age stages were not statistically significant. This is in consistent with what mentioned by El-Gebali (2000, pp534-536) that in younger age stages excitability mechanics and motor system activity organizing, as well as increasing metabolism. Their muscles are characterized with nerve process flexibility and contraction and extraction speed, He also indicates that applied studies recommended that the best age for developing motor speed is (910) years, and the best age for speed talents discovery is (9-12) years. This is due to body elasticity, nerve process easiness, and Easiness of forming reverses reactions. El_Nimr and El-Khatib(2000, p211) emphasize that 7-12 age stage is a sensitive age stage for speed training as the most speed development rate is happen as a result of nerve system development. It is recommended in this stage to concentrate on step rate and reaction speed exercises. This declare the reasons that the differences between other age stages were not statistically significant and this was opposite to what expected as it is supposed that reaction time to be less in older age stages compared with younger age stages, results was in opposite to this. Researcher return this to youngsters eagerness for participating in such international championship in this young age, especially this appeared in 50 meter race while in larger distance it was not clearly appear. 
Table (4)

Differences significance between boys and girls in reaction time (50meter race)

\begin{tabular}{|c|c|c|c|c|c|c|c|}
\hline \multirow{2}{*}{$\begin{array}{l}\text { Statistics } \\
\text { variables }\end{array}$} & \multicolumn{2}{|c|}{$\begin{array}{c}\text { B } \\
(n=567)\end{array}$} & \multicolumn{2}{|c|}{$\begin{array}{c}\text { Girls } \\
(\mathbf{n}=\mathbf{5 6 0})\end{array}$} & \multirow{2}{*}{$\begin{array}{c}\text { Means } \\
\text { difference }\end{array}$} & \multirow{2}{*}{$\begin{array}{c}(\mathrm{T}) \\
\text { value }\end{array}$} & \multirow{2}{*}{$\begin{array}{c}\text { significance } \\
\text { level }\end{array}$} \\
\hline & Mean & \pm SD & Mean & \pm SD & & & \\
\hline Reaction time & 0.76 & 0.21 & 0.77 & 0.25 & 0.01 & 0.58 & 0.56 \\
\hline
\end{tabular}

* Significant at 0.05 level

Table (4) results reveal that differences between boys and girls in reaction time for 50 meter results were not significant at the 0.05 level, as $\mathrm{T}$ calculated value was equal to (0.58) which is less than $\mathrm{T}$ significant value at 0.05 level.

Table (5) Reaction time descriptive statistics per swimming methods (50 meter race)

\begin{tabular}{l|l|l|l|c|c}
\hline \hline Variables & $\begin{array}{l}\text { Swimming } \\
\text { methods }\end{array}$ & $\mathbf{n}$ & Mean & Standard deviation & Maximum value \\
\hline \hline \multirow{5}{*}{ Reaction time } & Free & 350 & 0.83 & 0.17 & 1.17 \\
\cline { 2 - 6 } & Back & 233 & 0.63 & 0.20 & 0.98 \\
\cline { 2 - 6 } & Breast & 252 & 0.78 & 0.25 & 1.00 \\
\cline { 2 - 6 } & Butterfly & 292 & 0.77 & 0.26 & 1.00 \\
\cline { 2 - 6 } & Total & 1127 & 0.76 & 0.23 & 1.17 \\
\hline \hline
\end{tabular}

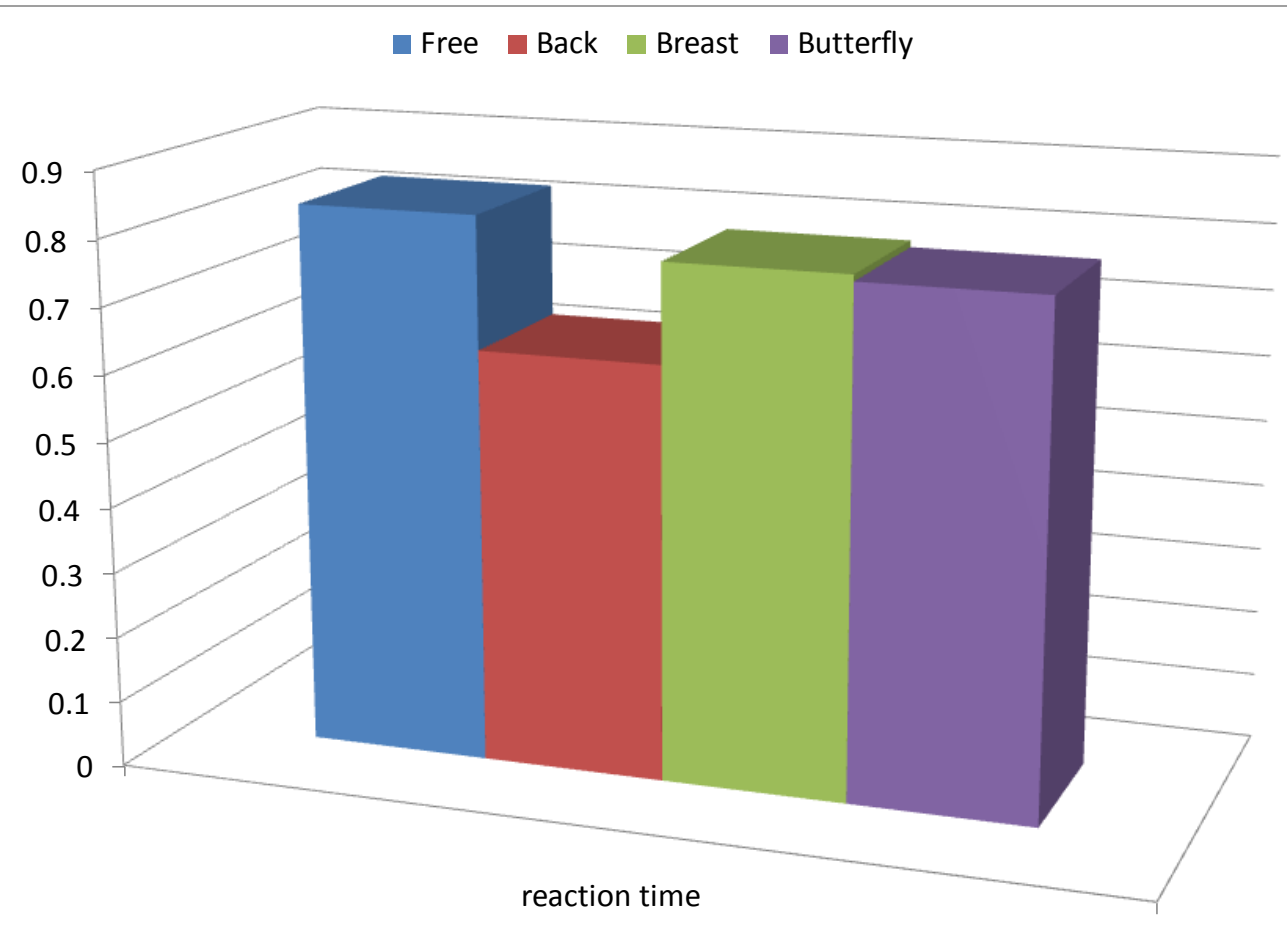

Figure (2) Reaction time per swimming methods (50 meter race) 
Table (6)

Reaction time Differences significance between swimming methods (50 Meter race)

\begin{tabular}{l|l|l|l|l|l|c}
\hline \hline $\begin{array}{l}\text { Statistics } \\
\text { variables }\end{array}$ & Variance source & $\begin{array}{c}\text { Squares } \\
\text { total }\end{array}$ & $\begin{array}{c}\text { degrees of } \\
\text { freedom }\end{array}$ & $\begin{array}{c}\text { Squares } \\
\text { mean }\end{array}$ & $\begin{array}{c}\text { F } \\
\text { Value }\end{array}$ & $\begin{array}{c}\text { Significance } \\
\text { Level (p) }\end{array}$ \\
\hline \hline \multirow{3}{*}{ Reaction time } & Between swimming methods & 5.84 & 3 & 1.95 & \multirow{2}{*}{$39.99 *$} & \multirow{2}{*}{0.00} \\
\cline { 2 - 5 } & Within swimming methods & 54.68 & 1123 & 0.05 & & \\
\cline { 2 - 5 } & Total & 60.52 & 1126 & & & \\
\hline \hline
\end{tabular}

* Significant at 0.05 level

Table (6) results reveal existence of statistically significant differences between swimming methods in reaction time (for 50 meter race) at 0.05 level, where F calculated value is greater than its significant value at 0.05 level and significance level $(\mathrm{P}<0.05)$ which necessitating conducting post average test to determine these differences direction and significance . the researcher will perform LSD test at 0.05 level.

Table (7)

\section{LSD test at 0.05 level to determine differences significance and direction between swimming} methods in reaction time ( for 50 meter race)

\begin{tabular}{|c|c|c|c|c|}
\hline Variables & $\begin{array}{c}\text { main swimming } \\
\text { method }\end{array}$ & $\begin{array}{c}\text { Sub swimming } \\
\text { method }\end{array}$ & Mean difference & Significance level \\
\hline \multirow{12}{*}{$\begin{array}{l}\text { Reaction time } \\
\text { (50 meter race) }\end{array}$} & \multirow{3}{*}{ Free } & Back & $20105 *$ & 0.00 \\
\hline & & Breast & $0.05046^{*}$ & 0.01 \\
\hline & & Butterfly & $0.05954 *$ & 0.00 \\
\hline & \multirow{3}{*}{ Back } & Free & $-0.20105^{*}$ & 0.00 \\
\hline & & Breast & $-0.15059 *$ & 0.00 \\
\hline & & Butterfly & $-0.14152 *$ & 0.00 \\
\hline & \multirow{3}{*}{ Breast } & Free & $-0.05046^{*}$ & 0.01 \\
\hline & & back & $0.15059 *$ & 0.00 \\
\hline & & Butterfly & 0.01 & 0.63 \\
\hline & \multirow{3}{*}{ Butterfly } & Free & $-0.05954 *$ & 0.00 \\
\hline & & back & $0.14152 *$ & 0.00 \\
\hline & & Breast & -0.01 & 0.63 \\
\hline
\end{tabular}

* Mean difference is significant at 0.05 level.

Positive signal means that differences in the direction of main group and negative signal means that differences in the direction of the sub-group

Table(7) results declare that that there were significant differences between back stroke and free, butterfly and breast strokes in favor of back strokes. There were also differences between breast stroke, and free and butterfly stroke in favor of breast stroke. Also there were a difference between butterfly stroke and free stroke in favor of butterfly stroke

The reaction in tine in back stroke was less than other swimming methods (butterfly, free and breast) in $50 \mathrm{~m}$ distance race. Researcher attribute this difference to that back stroke start differs from other swimming methods start as it is done from sown the pool unlike other swimming methods where start is from above the pool and this is was explained by Abdel-Fattah (1997).Breast swimmers have less reaction time than free and butterfly swimmers 50-meter race and butterfly swimmers have less reaction than free swimmers in 50-meter race

This was opposite of what was expected; as free stroke reaction time in 50 meter races is usually less than other swimming methods. Researcher return this to possibility of start training for 
free stroke swimmers less than breast and butterfly simmers; as AlShook (2005) in his study stated that faster reaction times is usually for swimmers trained with intensive training

Table (8) Reaction time descriptive statistics per age stages (100 meter race)

\begin{tabular}{l|l|l|l|l|l}
\hline \hline Variables & Age Stage & n & Mean & Standard deviation & Maximum value \\
\hline \hline \multirow{5}{*}{ Reaction time } & Born in 96-97 & 39 & 0.75 & 0.28 & 0.98 \\
\cline { 2 - 6 } & Born in 94-95 & 158 & 0.73 & 0.27 & 1.00 \\
\cline { 2 - 6 } & Born in 92-93 & 208 & 0.81 & 0.16 & 1.00 \\
\cline { 2 - 6 } & Born in 90-91 & 170 & 0.78 & 0.21 & 0.99 \\
\cline { 2 - 6 } & General & 163 & 0.78 & 0.20 & 0.99 \\
\cline { 2 - 6 } & Total & 738 & 0.78 & 0.22 & 1.00 \\
\hline \hline
\end{tabular}

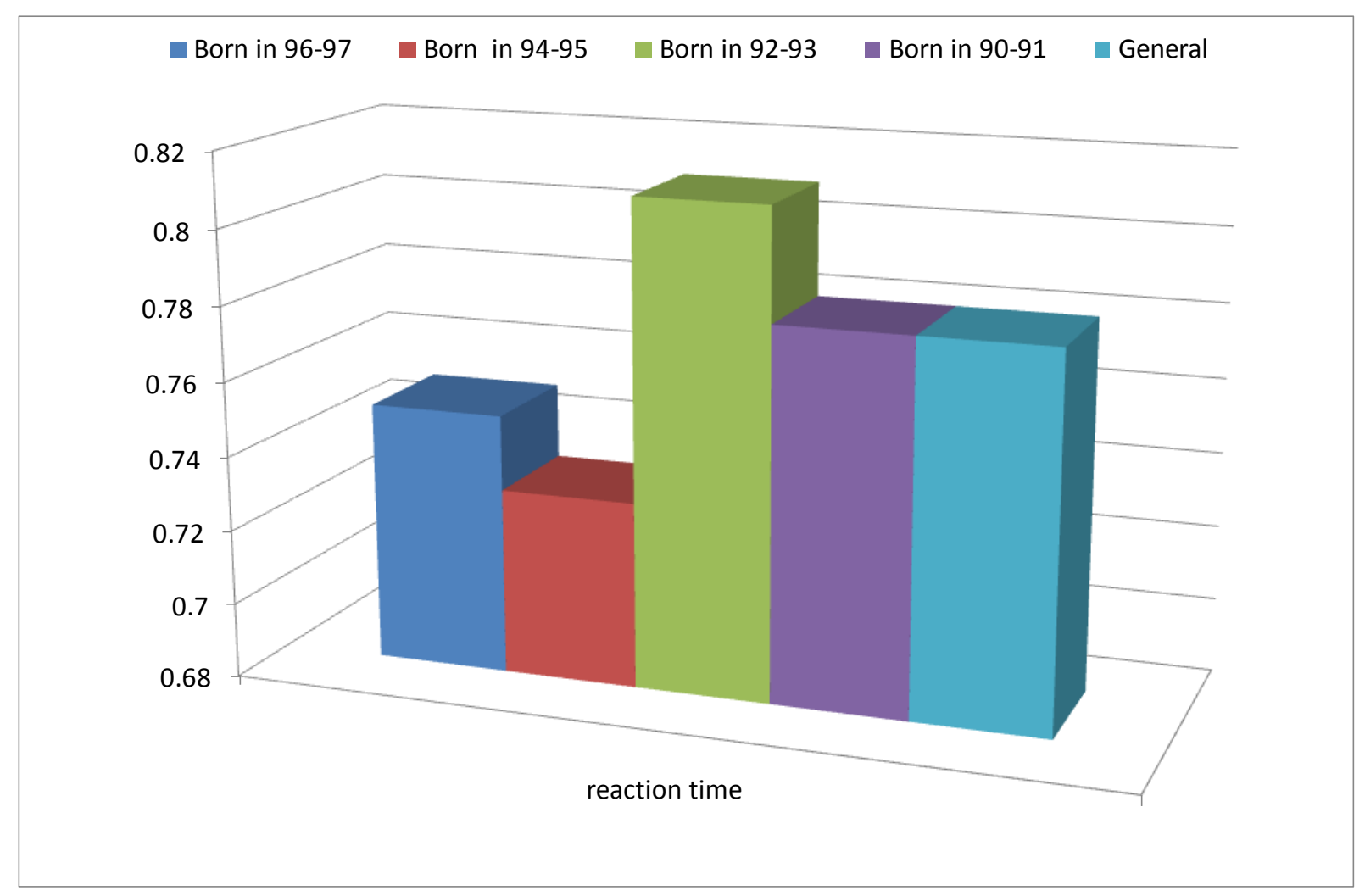

Figure (3) Reaction time per age stages (100 meter race)

Table (9)

Reaction time Differences significance between age stages (100 Meter race)

\begin{tabular}{l|l|c|c|c|c|c}
\hline \hline \multirow{2}{*}{$\begin{array}{l}\text { Statistics } \\
\text { variables }\end{array}$} & Variance source & $\begin{array}{c}\text { Squares } \\
\text { total }\end{array}$ & $\begin{array}{c}\text { degrees of } \\
\text { freedom }\end{array}$ & $\begin{array}{c}\text { Squares } \\
\text { mean }\end{array}$ & $\begin{array}{c}\text { F } \\
\text { Value }\end{array}$ & $\begin{array}{c}\text { Significance } \\
\text { Level } \\
(\mathbf{p})\end{array}$ \\
\hline \hline \multirow{3}{*}{ Reaction time } & Between age stages & 0.56 & 4 & 0.14 & \multirow{2}{*}{$3.01 *$} & \multirow{2}{*}{0.02} \\
\cline { 2 - 5 } & Within age stages & 33.85 & 733 & 0.05 & & \\
\cline { 2 - 5 } & Total & 34.41 & 737 & & & \\
\hline \hline
\end{tabular}

Table (9) results reveal existence of statistically significant differences between ages stages in reaction time (for 100 meter race) at 0.05 level, where $F$ calculated value is greater than its significant value at 0.05 level and significance level $(\mathrm{P}<0.05)$ which necessitating conducting post 
average test to determine these differences direction and significance. Theresearcher will perform LSD test at 0.05 level.

Table (10)

LSD test at 0.05 level to determine differences significance and direction between age stages in reaction time ( for 100 meter race)

\begin{tabular}{|c|c|c|c|c|}
\hline Variables & main age stage & Sub age stage & Mean difference & Significance level \\
\hline \multirow{20}{*}{$\begin{array}{l}\text { Reaction time } \\
\text { (100 meter race) }\end{array}$} & \multirow{4}{*}{ Born in $96-97$ (D) } & Born in $94-95(\mathrm{C})$ & 0.02 & 0.62 \\
\hline & & Born in $92-93(\mathrm{~B})$ & -0.06 & 0.13 \\
\hline & & Born in $90-91(\mathrm{~A})$ & -0.03 & 0.42 \\
\hline & & OFFENE & -0.03 & 0.39 \\
\hline & \multirow{4}{*}{ Born in $94-95(C)$} & Born in $96-97$ (D) & -0.02 & 0.62 \\
\hline & & Born in $92-93(\mathrm{~B})$ & $-0.07586 *$ & 0.00 \\
\hline & & Born in $90-91(\mathrm{~A})$ & $-0.05008 *$ & 0.04 \\
\hline & & OFFENE & $-0.05226 *$ & 0.03 \\
\hline & \multirow{4}{*}{ Born in $92-93(B)$} & Born in $96-97$ (D) & 0.06 & 0.13 \\
\hline & & Born in $94-95(\mathrm{C})$ & $.07586 *$ & 0.00 \\
\hline & & Born in $90-91(\mathrm{~A})$ & 0.03 & 0.25 \\
\hline & & OFFENE & 0.02 & 0.29 \\
\hline & \multirow{4}{*}{ Born in $90-91(\mathrm{~A})$} & Born in $96-97$ (D) & 0.03 & 0.42 \\
\hline & & Born in $94-95$ (c) & $0.05008 *$ & 0.04 \\
\hline & & Born in $92-93(\mathrm{~B})$ & -0.03 & 0.25 \\
\hline & & OFFENE & 0.00 & 0.93 \\
\hline & \multirow{4}{*}{ OFFENE } & Born in 96-97 (D) & 0.03 & 0.39 \\
\hline & & Born in $94-95(\mathrm{C})$ & $0.05226 *$ & 0.03 \\
\hline & & Born in $92-93(\mathrm{~B})$ & -0.02 & 0.29 \\
\hline & & Born in $90-91(\mathrm{~A})$ & 0.00 & 0.93 \\
\hline
\end{tabular}

* Mean difference is significant at 0.05 level.

Positive signal means that differences in the direction of main group and negative signal means that differences in the direction of the sub-group

Table (10) results reveals that there were statistically significant differences between born in 94-95 (C) and between born in 92-93 (B), born in 90-91 (A) general (OFFENE) in favor of born in 94-95 (C). The reaction time was less in born in 12-13 years stage (born 94 -95 C) than all other age stages (14-15 years old (born in 92 -93 (B)), 16 -17 years old (born in 90 - 91 (A)), and general (OFFENE).Table results also declared that reaction time for 10-11 years was less than 16-17 years stage in 100-meter races.

This is in consistent with what mentioned by El-Gebali (2000, pp534-536) that in younger age stages excitability mechanics and motor system activity organizing, as well as increasing metabolism. Their muscles are characterized with nerve process flexibility and contraction and extraction speed, He also indicates that applied studies recommended that the best age for developing motor speed is (910) years, and the best age for speed talents discovery is (9-12) years. This is due to body elasticity, nerve process easiness, and Easiness of forming reverses reactions. El_Nimr and El-Khatib(2000,p211) emphasize that 7-12 age stage is a sensitive age stage for speed training as the most speed development rate is happen as a result of nerve system development. It is recommended in this stage to concentrate on step rate and reaction speed exercises. Researcher through practical experience as a coach for long time - return lower reaction time within younger age stages (10-11, and 12-13 years) to their eagerness and concentration on their participation in a 
major international championship like this; also older swimmers have a chance to participate in both race qualifying and final phase which make their reaction times relatively high compared with younger stages who had only one chance to participate in the race (where final race is with time).

Table (11)

Differences significance between boys and girls in reaction time (100 meter race)

\begin{tabular}{|l|c|c|c|c|c|c|c|}
\hline \hline \multirow{2}{*}{$\begin{array}{l}\text { Statistics } \\
\text { variables }\end{array}$} & \multicolumn{2}{|c|}{$\begin{array}{c}\text { B } \\
(\mathbf{n}=\mathbf{3 8 7})\end{array}$} & \multicolumn{2}{c|}{$\begin{array}{c}\text { Girls } \\
(\mathbf{n = 3 5 1})\end{array}$} & $\begin{array}{c}\text { Means } \\
\text { difference }\end{array}$ & $\begin{array}{c}\text { (T) } \\
\text { value }\end{array}$ & $\begin{array}{c}\text { significance } \\
\text { level }\end{array}$ \\
\cline { 2 - 5 } & Mean & $\mathbf{\pm S D}$ & Mean & $\mathbf{\pm S D}$ & & 1.24 & 0.21 \\
\hline \hline Reaction time & 0.79 & 0.18 & 0.77 & 0.25 & 0.02 & \\
\hline \hline
\end{tabular}

* Significant at 0.05 level

Table (11) results reveal that differences between boys and girls in reaction time for 100 meter results were not significant at the 0.05 level, as $\mathrm{T}$ calculated value was equal to (1.24) which is less than T significant value at 0.05 level.

Table (12) Reaction time descriptive statistics per swimming methods (100 meter race)

\begin{tabular}{l|l|l|l|c|c}
\hline \hline Variables & $\begin{array}{l}\text { Swimming } \\
\text { methods }\end{array}$ & $\mathbf{n}$ & Mean & Standard deviation & Maximum value \\
\hline \hline \multirow{4}{*}{ Reaction time } & Free & 289 & 0.79 & 0.24 & 1.00 \\
\cline { 2 - 7 } & Back & 167 & 0.67 & 0.15 & 0.98 \\
\cline { 2 - 6 } & Breast & 152 & 0.82 & 0.23 & 1.00 \\
\cline { 2 - 6 } & Butterfly & 130 & 0.84 & 0.18 & 1.00 \\
\cline { 2 - 6 } & Total & 738 & 0.78 & 0.22 & 1.00 \\
\hline \hline
\end{tabular}

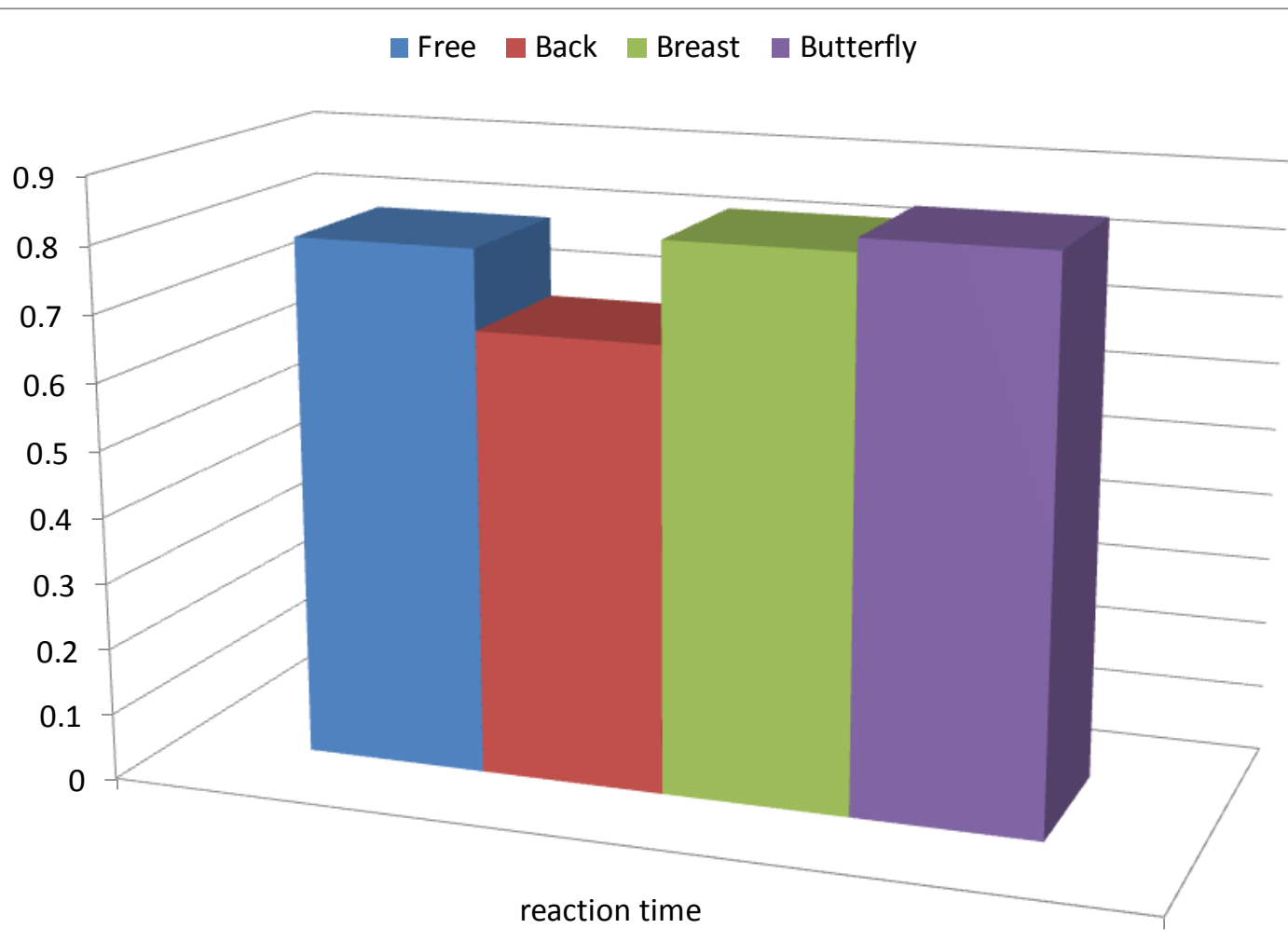

Figure (4) Reaction time per swimming methods (100 meter race) 
Table (13)

Reaction time Differences significance between swimming methods (100 Meter race)

\begin{tabular}{l|l|c|c|c|c|c}
\hline \hline $\begin{array}{l}\text { Statistics } \\
\text { variables }\end{array}$ & \multicolumn{1}{|c|}{ Variance source } & $\begin{array}{c}\text { Squares } \\
\text { total }\end{array}$ & $\begin{array}{c}\text { degrees of } \\
\text { freedom }\end{array}$ & $\begin{array}{c}\text { Squares } \\
\text { mean }\end{array}$ & $\begin{array}{c}\text { F } \\
\text { Value }\end{array}$ & $\begin{array}{c}\text { Significance } \\
\text { Level (p) }\end{array}$ \\
\hline \hline & Between swimming methods & 2.65 & 3 & 0.88 & & \multirow{2}{*}{$20.44 *$} \\
\cline { 2 - 5 } Reaction time & Within swimming methods & 31.75 & 734 & 0.04 & & \\
\cline { 2 - 6 } & Total & 34.41 & 737 & & & \\
\hline \hline
\end{tabular}

* Significant at 0.05 level

Table (13) results reveal existence of statistically significant differences between swimming methods in reaction time (for 100 meter race) at 0.05 level, where F calculated value is greater than its significant value at 0.05 level and significance level $(\mathrm{P}<0.05)$ which necessitating conducting post average test to determine these differences direction and significance . the researcher will perform LSD test at 0.05 level.

Table (14)

LSD test at 0.05 level to determine differences significance and direction between swimming methods in reaction time (for 100 meter race)

\begin{tabular}{|c|c|c|c|c|}
\hline Variables & $\begin{array}{l}\text { main swimming } \\
\text { method }\end{array}$ & $\begin{array}{c}\text { Sub swimming } \\
\text { method }\end{array}$ & Mean difference & Significance level \\
\hline \multirow{12}{*}{$\begin{array}{l}\text { Reaction time } \\
\text { (100 meter race) }\end{array}$} & \multirow{3}{*}{ Free } & Back & $0.12038 *$ & 0.00 \\
\hline & & Breast & -0.03 & 0.19 \\
\hline & & Butterfly & $-0.04485 *$ & 0.04 \\
\hline & \multirow{3}{*}{ Back } & Free & $-0.12038 *$ & 0.00 \\
\hline & & Breast & $-0.14747 *$ & 0.00 \\
\hline & & Butterfly & $-0.16523 *$ & 0.00 \\
\hline & \multirow{3}{*}{ Breast } & Free & 0.03 & 0.19 \\
\hline & & back & $0.14747 *$ & 0.00 \\
\hline & & Butterfly & -0.02 & 0.48 \\
\hline & \multirow{3}{*}{ Butterfly } & Free & $0.04485 *$ & 0.04 \\
\hline & & back & $0.16523 *$ & 0.00 \\
\hline & & Breast & 0.02 & 0.48 \\
\hline
\end{tabular}

* Mean difference is significant at 0.05 level.

Positive signal means that differences in the direction of main group and negative signal means that differences in the direction of the sub-group

Table (14 results) reveals existence of statistically significant differences between back stroke and between breast, butterfly and free strokes in favor of back stroke, this is in agreement with what mentioned above that back stroke start differs than other swimming methods start in that it is done from pool down in opposite of other swimming methods. Table results also indicate existence of statistically significant differences between butterfly and free strokes in favor of butterfly, and that reaction time in free stroke was less than that of butterfly stroke. Researcher attribute this to that reaction time in free stroke is usually better than butterfly and breast strokes due to that free stroke is the fastest swimming method which make reaction time in free stroke usually less than breast and butterfly strokes. 
Table (15) Reaction time descriptive statistics per age stages (100 meter race)

\begin{tabular}{l|l|c|c|c|c}
\hline \hline Variables & Age Stage & n & Mean & Standard deviation & Maximum value \\
\hline \hline \multirow{5}{*}{ Reaction time } & Born in 96-97 & 19 & 0.67 & 0.37 & 1.00 \\
\cline { 2 - 6 } & Born in 94-95 & 120 & 0.69 & 0.32 & 1.08 \\
\cline { 2 - 6 } & Born in 92-93 & 171 & 0.76 & 0.26 & 1.84 \\
\cline { 2 - 6 } & Born in 90-91 & 139 & 0.80 & 0.20 & 0.99 \\
\cline { 2 - 6 } & General & 109 & 0.79 & 0.20 & 0.99 \\
\cline { 2 - 6 } & Total & 558 & 0.76 & 0.26 & 1.84 \\
\hline \hline
\end{tabular}

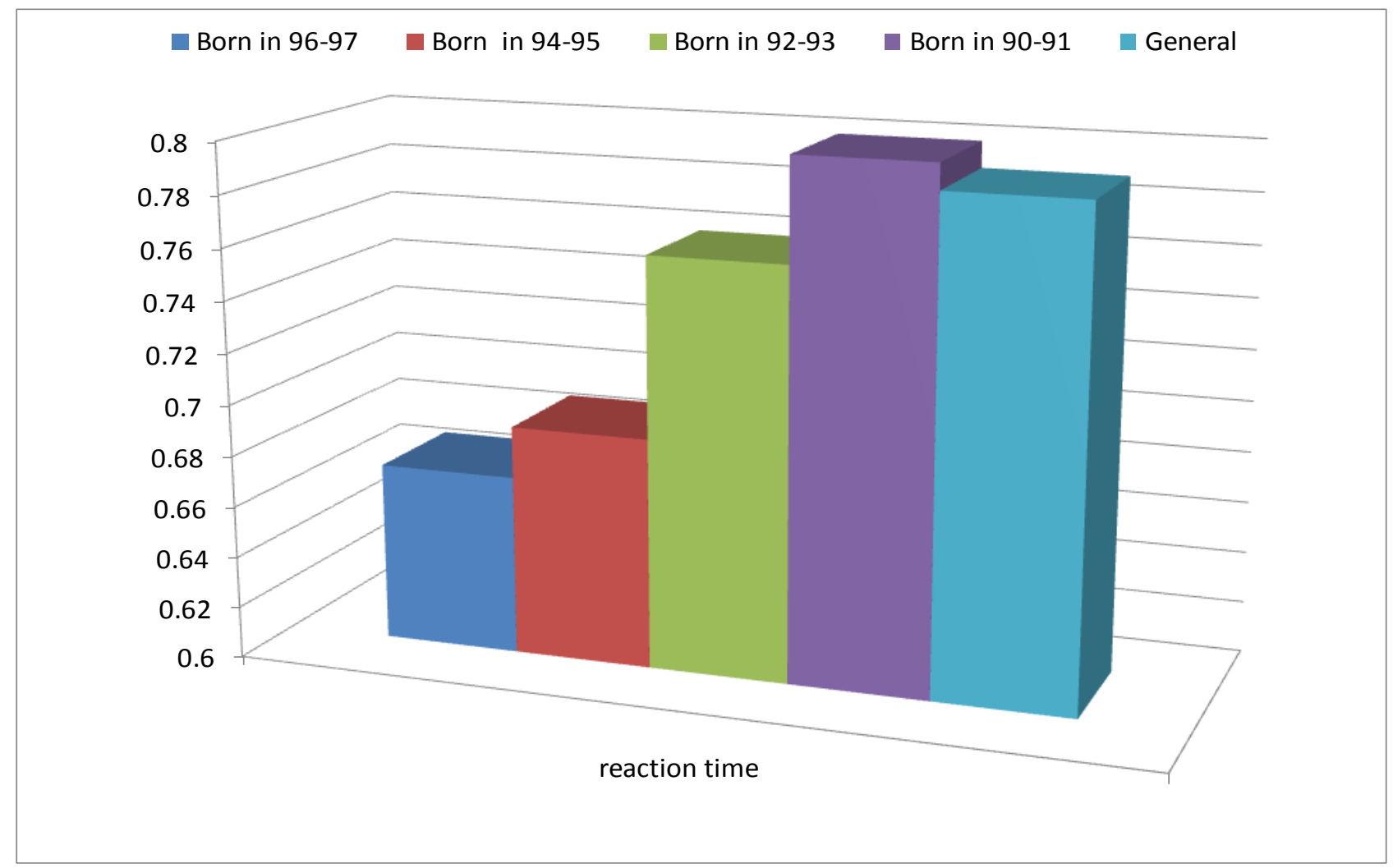

Figure (5) Reaction time per age stages (100 meter race)

Table (16)

Reaction time Differences significance between age stages (100 Meter race)

\begin{tabular}{l|l|c|c|c|c|c}
\hline \hline $\begin{array}{l}\text { Statistics } \\
\text { variables }\end{array}$ & Variance source & $\begin{array}{c}\text { Squares } \\
\text { total }\end{array}$ & $\begin{array}{c}\text { degrees of } \\
\text { freedom }\end{array}$ & $\begin{array}{c}\text { Squares } \\
\text { mean }\end{array}$ & $\begin{array}{c}\text { F } \\
\text { Value }\end{array}$ & $\begin{array}{c}\text { Significance } \\
\text { Level } \\
(\mathbf{p})\end{array}$ \\
\hline \hline \multirow{2}{*}{ Reaction time } & Between age stages & 1.03 & 4 & 0.26 & \multirow{2}{*}{$4.01 *$} & \multirow{2}{*}{0.00} \\
\cline { 2 - 5 } & Within age stages & 35.69 & 553 & 0.06 & & \\
\cline { 2 - 5 } & Total & 36.73 & 557 & \multicolumn{2}{|c}{ * Significant at 0.05 level } \\
\hline \hline
\end{tabular}

Table (16) results reveal existence of statistically significant differences between ages stages in reaction time (for 100 meter race) at 0.05 level, where $F$ calculated value is greater than its significant value at 0.05 level and significance level $(\mathrm{P}<0.05)$ which necessitating conducting post average test to determine these differences direction and significance. The researcher will perform LSD test at 0.05 level. 
Table (17)

LSD test at 0.05 level to determine differences significance and direction between age stages in reaction time ( for 100 meter race)

\begin{tabular}{|c|c|c|c|c|}
\hline Variables & main age stage & Sub age stage & Mean difference & $\begin{array}{l}\text { Significance level } \\
\end{array}$ \\
\hline \multirow{20}{*}{$\begin{array}{l}\text { Reaction time } \\
\text { (100 meter race) }\end{array}$} & \multirow{4}{*}{ Born in $96-97$ (D) } & Born in 94-95 (C) & -0.02 & 0.71 \\
\hline & & Born in $92-93(B)$ & -0.10 & 0.12 \\
\hline & & Born in $90-91(\mathrm{~A})$ & $-0.13158 *$ & 0.03 \\
\hline & & OFFENE & -0.12 & 0.06 \\
\hline & \multirow{4}{*}{ Born in $94-95(\mathrm{C})$} & Born in 96-97 (D) & 0.02 & 0.71 \\
\hline & & Born in $92-93(B)$ & $-0.07231 *$ & 0.02 \\
\hline & & Born in $90-91(\mathrm{~A})$ & $-0.10833 *$ & 0.00 \\
\hline & & OFFENE & $-0.09705 *$ & 0.00 \\
\hline & \multirow{4}{*}{ Born in $92-93(\mathrm{~B})$} & Born in 96-97 (D) & 0.10 & 0.12 \\
\hline & & Born in $94-95(\mathrm{C})$ & $.07231 *$ & 0.02 \\
\hline & & Born in $90-91$ (A) & -0.04 & 0.21 \\
\hline & & OFFENE & -0.02 & 0.43 \\
\hline & \multirow{4}{*}{ Born in $90-91(\mathrm{~A})$} & Born in 96-97 (D) & $0.13158 *$ & 0.03 \\
\hline & & Born in $94-95(\mathrm{c})$ & $.10833 *$ & 0.00 \\
\hline & & Born in $92-93(\mathrm{~B})$ & 0.04 & 0.21 \\
\hline & & OFFENE & 0.01 & 0.73 \\
\hline & \multirow{4}{*}{ OFFENE } & Born in 96-97 (D) & 0.12 & 0.06 \\
\hline & & Born in $94-95(\mathrm{C})$ & $.09705 *$ & 0.00 \\
\hline & & Born in $92-93(B)$ & 0.02 & 0.43 \\
\hline & & Born in $90-91$ (A) & -0.01 & 0.73 \\
\hline
\end{tabular}

* Mean difference is significant at 0.05 level.

Positive signal means that differences in the direction of main group and negative signal means that differences in the direction of the sub-group

Table (17) results reveals that there were statistically significant differences between born in 94-95 (C) and between born in 92-93 (B), born in 90-91 (A) general (OFFENE) in favor of born in 94-95 (C). There were also significant differences between born in 96-97 (D) and born in 90-91 (C) in favor of born in 96-97(D). The reaction time was less in born in 12-13 years stage (born 94 -95 C) than all other age stages (14-15 years old (born in 92 -93 (B)), 16 -17 years old (born in 90 - 91 (A)), and general (OFFENE). Table results also declared that reaction time for 10-11 years was less than $16-17$ years stage in 200-meter races.

This is in consistent with what previously mentioned and confirmed by by El-Gebali (2000, pp534-536) El_Nimr and El-Khatib(2000, p211)and that the researcher - through practical experience as a coach for long time - as mentioned above return lower reaction time within younger age stages (10-11, and 12-13 years) to their eagerness and concentration on their participation in a major international championship like this; also older swimmers have a chance to participate in both race qualifying and final phase which make their reaction times relatively high compared with younger stages who had only one chance to participate in the race (where final race is with time).

Table (18) Differences significance between boys and girls in reaction time (100 meter race)

\begin{tabular}{|l|c|c|c|c|c|c|c|}
\hline \hline \multirow{2}{*}{$\begin{array}{l}\text { Statistics } \\
\text { variables }\end{array}$} & \multicolumn{2}{|c|}{$\begin{array}{c}\text { B } \\
(\mathbf{n}=\mathbf{3 8 7})\end{array}$} & \multicolumn{2}{c|}{$\begin{array}{c}\text { Girls } \\
(\mathbf{n = 3 5})\end{array}$} & $\begin{array}{c}\text { Means } \\
\text { difference }\end{array}$ & $\begin{array}{c}\text { (T) } \\
\text { value }\end{array}$ & $\begin{array}{c}\text { significance } \\
\text { level }\end{array}$ \\
\cline { 2 - 5 } & Mean & $\mathbf{\pm S D}$ & Mean & $\mathbf{\pm S D}$ & & \\
\hline \hline Reaction time & 0.78 & 0.22 & 0.74 & 0.29 & 0.04 & 1.89 & 0.06 \\
\hline \hline
\end{tabular}


Table (18) results reveal that differences between boys and girls in reaction time for 100 meter results were not significant at the 0.05 level, as T calculated value was equal to (1.89) which is less than T significant value at 0.05 level.

Table (19)

Reaction time descriptive statistics per swimming methods (100 meter race)

\begin{tabular}{l|l|l|c|c|c}
\hline \hline Variables & $\begin{array}{l}\text { Swimming } \\
\text { methods }\end{array}$ & $\mathbf{n}$ & Mean & Standard deviation & Maximum value \\
\hline \hline \multirow{5}{*}{ Reaction time } & Free & 217 & 0.77 & 0.27 & 1.00 \\
\cline { 2 - 6 } & Back & 124 & 0.70 & 0.17 & 1.84 \\
\cline { 2 - 6 } & Breast & 144 & 0.73 & 0.32 & 1.00 \\
\cline { 2 - 6 } & Butterfly & 73 & 0.87 & 0.12 & 1.08 \\
\cline { 2 - 6 } & Total & 558 & 0.76 & 0.26 & 1.84 \\
\hline \hline
\end{tabular}

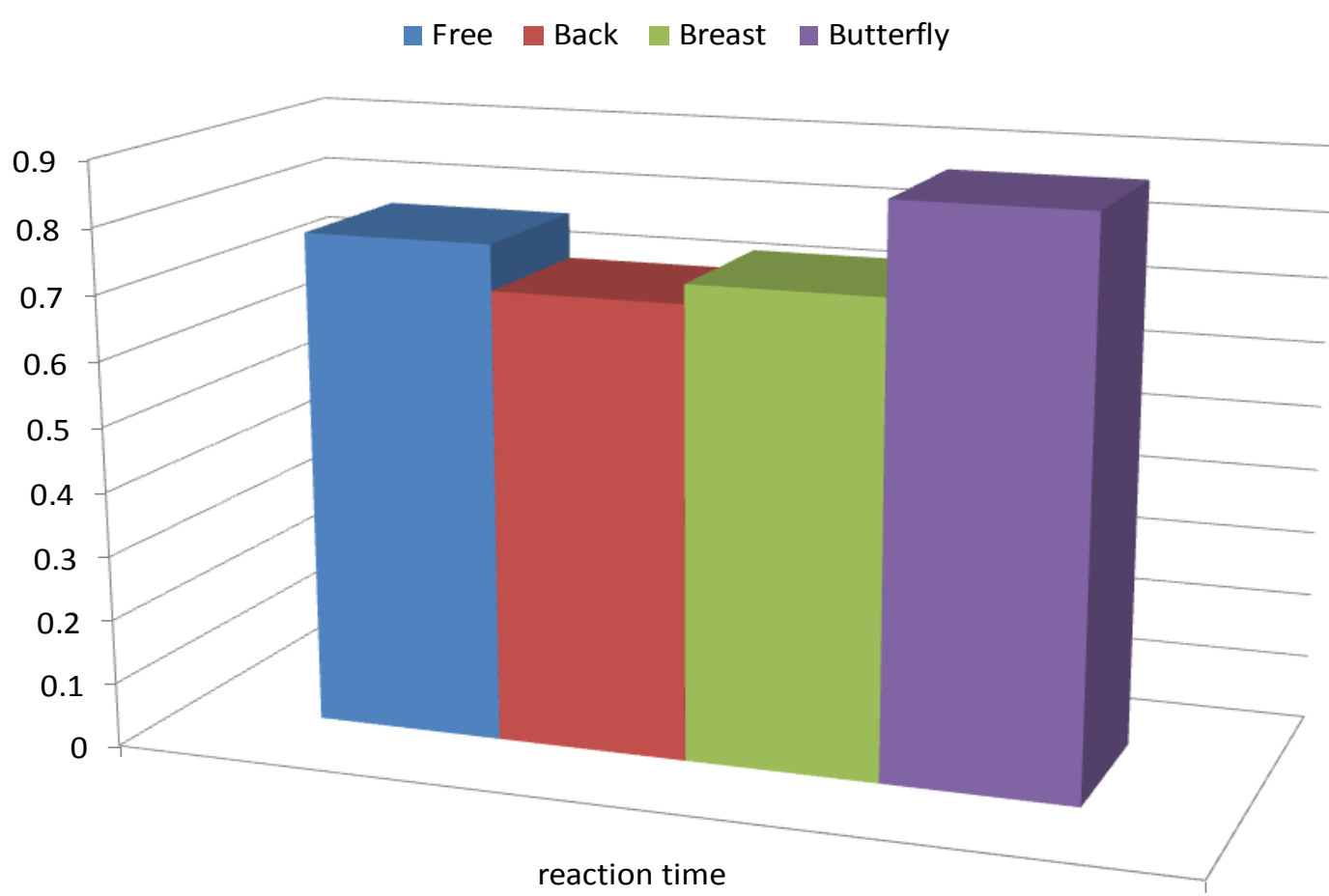

Figure (6) Reaction time per swimming methods (100 meter race)

Table (20)

Reaction time Differences significance between swimming methods (100 Meter race)

\begin{tabular}{l|l|c|c|c|c|c}
\hline $\begin{array}{l}\text { Statistics } \\
\text { variables }\end{array}$ & Variance source & $\begin{array}{c}\text { Squares } \\
\text { total }\end{array}$ & $\begin{array}{c}\text { degrees of } \\
\text { freedom }\end{array}$ & $\begin{array}{c}\text { Squares } \\
\text { mean }\end{array}$ & $\begin{array}{c}\text { F } \\
\text { Value }\end{array}$ & $\begin{array}{c}\text { Significance } \\
\text { Level (p) }\end{array}$ \\
\hline \hline \multirow{3}{*}{ Reaction time } & Between swimming methods & 1.53 & 3 & 0.51 & \multirow{2}{*}{$8.05 *$} & \multirow{2}{*}{0.00} \\
\cline { 2 - 5 } & Within swimming methods & 35.19 & 554 & 0.06 & & \\
\cline { 2 - 5 } & Total & 36.73 & 557 & & & \\
\hline \hline
\end{tabular}

* Significant at 0.05 level

Table (20) results reveal existence of statistically significant differences between swimming methods in reaction time (for 100 meter race) at 0.05 level, where F calculated value is greater than its significant value at 0.05 level and significance level $(\mathrm{P}<0.05)$ which necessitating conducting 
post average test to determine these differences direction and significance . the researcher will perform LSD test at 0.05 level.

Table (21)

LSD test at 0.05 level to determine differences significance and direction between swimming methods in reaction time ( for $\mathbf{1 0 0}$ meter race)

\begin{tabular}{|c|c|c|c|c|}
\hline Variables & $\begin{array}{c}\text { main swimming } \\
\text { method }\end{array}$ & $\begin{array}{c}\begin{array}{c}\text { Sub swimming } \\
\text { method }\end{array} \\
\end{array}$ & Mean difference & Significance level \\
\hline \multirow{12}{*}{$\begin{array}{l}\text { Reaction time } \\
\text { (100 meter race) }\end{array}$} & \multirow{3}{*}{ Free } & "Back & $0.07833 *$ & 0.01 \\
\hline & & Breast & 0.04 & 0.12 \\
\hline & & Butterfly & $-0.09516 *$ & 0.01 \\
\hline & \multirow{3}{*}{ Back } & Free & $-0.07833 *$ & 0.01 \\
\hline & & Breast & -0.04 & 0.24 \\
\hline & & Butterfly & $-0.17349 *$ & 0.00 \\
\hline & \multirow{3}{*}{ Breast } & Free & -0.04 & 0.12 \\
\hline & & back & 0.04 & 0.24 \\
\hline & & Butterfly & $-0.13688 *$ & 0.00 \\
\hline & \multirow{3}{*}{ Butterfly } & Free & $0.09516 *$ & 0.01 \\
\hline & & back & $0.17349 *$ & 0.00 \\
\hline & & Breast & $0.13688 *$ & 0.00 \\
\hline
\end{tabular}

* Mean difference is significant at 0.05 level.

Positive signal means that differences in the direction of main group and negative signal means that differences in the direction of the sub-group

Table (21 results) reveals existence of statistically significant differences between back stroke and between breast, butterfly and free strokes in favor of back stroke, this is in agreement with what mentioned above that back stroke start differs than other swimming methods start in that it is done from pool down in opposite of other swimming methods. Table results also indicate that reaction time in 200 meter free stroke was less than that for 3oo meter breast and butterfly stroke.. Researcher attribute this - as mentioned above - to that reaction time in free stroke is usually better than butterfly and breast strokes due to that free stroke is the fastest swimming method which make reaction time in free stroke usually less than breast and butterfly strokes.

\section{Conclusions:} concluded:

In light of research results, procedures and statistical work the following could be

1- Reaction time in (10-11) age stage is less than (12-13), (14-15), (16-17) age stages and general in 50 meter races.

2- Reaction time in (12-13) age stage is less than (14-15), (16-17) age stages and general in 100 meters and 200 meters races, and reaction time in (10-11) age stage is less than (16-17) age stage in 200 meter race

3- There were no statistically significant differences between boys and girls in all races (50, 100, and 200 meters)

4- Reaction time in back stroke was less than other swimming method (free, butterfly and breast) in all races $(50,100$, and 200 meters)

5- Reaction time in breast stroke was less than (free, butterfly) strokes in 50 meter race, also reaction time in butterfly stroke was less than free stroke in 50 meter race. 
6- Reaction time in free stroke was less than butterfly stroke in 100 and 200 meter races, and less than breast stroke in 200 meter. Reaction time in breast stroke was less than butterfly stroke in 200 meter race.

\section{Recommendations:}

Based on research results, sample and objectives, and research sample and guided by the conclusions the researcher recommends the following:

1- Training programs for short distance swimmers (specially 50, 100, and 200m) must include training session for developing swimmers' reaction time and response speed

2- Coaches should make sure that training programs include special exercises to develop junior simmers' response speed, through well training on correct start with many repetitions as reaction time is vital and influential part in competition, especially in speed competitions, where the right start may contribute to race total time.

3- Coach and swimmer should analyze reaction time and race final time, which appears on the official result board, particularly if the swimmer has final races

4- Coach should keep evaluation form for every swimmer for different swimming types and distances, to find out simmer's reaction time improvement.

5- Coach must take into account individual differences between swimmers and conduct test for every swimmer to determine the appropriate starting type as shown in most studies results

6- Conduct research and studies to train swimmers (all specialties) on back swimming start and identify its effect on improving reaction time for other swimming methods (free, Butterfly, and breast).

\section{References}

1.

2.

3.

4.

5.

6.

7.
Abdel-Fattah, Abul-Ela, and Sayed, Ahmed Nasreddin(1993): Fitness Physiology, $1^{\text {st }}$ ed., Arab Thought House, Cairo. (In Arabic language)

Abdel-Fattah Abul-Ela Ahmed (1994): upper levels swimming training, $1^{\text {st }}$ ed., Arab Thought House, Cairo. (In Arabic language).

Abdel-Fattah, Ahmed Abul-Ela (1997): sports training - physiological bases, $1^{\text {st }}$ ed., Arab Thought House, Cairo. (In Arabic language)

Abdel-Hamid, Kamal, and Hassanein, Mohamed Sobhi (1997): Arab Thought House, Cairo. (In Arabic language)

Abdel-Hamid,Kamal, and Hassanein, Mohamed Sobhi (2001): modern handball Quadripartite, Book publishing center, Cairo. (In Arabic language)

AlShook, Ali Malk (2005): Motor response speed and its relationship with (50 m) butterfly swimming completion, Journal of Physical Education - Vol. 14- Baghdad University, Faculty of Political Science. (In Arabic language)

Beretić I, Đurović M, and Okičić T (2012): Influence of the back plate on kinematical starting parameter changes in elite male serbianswimmers, Physical Education and Sport Vol. 10, N 2, 2012, pp. 135 - 140. Available at:

http://facta.junis.ni.ac.rs/pe/pe201202/pe201202-07.pdf

8.

El-Gebali, Owis (2000): Sports training (theory and applications), G.M.S publication, Cairo. (In Arabic Language)

9.
El_Nimr, Abd El-Aziz, and El-Khatib, Nariman (2000): Physical preparation and weight training for juniors, Professors Sports Book, Cairo. . (In Arabic Language) 
10.

Garcia-Hermoso A., Escalante Y, Arellano R, Navarro F, Domínguez AM.and Saavedra JM (2013): Relationship between Final Performance and Block Times with the Traditional and the New Starting Platforms with A Back Plate in International Swimming Championship 50-M and 100-M Freestyle Events, Journal of Sports Science and Medicine, December 12 (4), pp 698-706. Available at:

11. http://www.ncbi.nlm.nih.gov/pubmed/24421729

12. Hammad, Mufti Ibrahim(1990): attack in football, Arab Thought House, Cairo. (In Arabic language)

13. Hassanein, Mohamed Sobhi (1995): Measurement and Evaluation in Physical Education and Sports, $3^{\text {rd }}$ ed., Arab Thought House, Cairo. (In Arabic language)

14. Hassanein, Mohamed Sobhi, Moafi, Ahmed Kesra (1998): Encyclopedia of Sports practical training, $1^{\text {st }}$ ed., book center. Cairo. (In Arabic language)

15. Hussein, QassimHassan(1998): Sports Training Science for different ages, Arab Thought House, Cairo. (In Arabic language)

16. Kennefick M., Maslovat D. Carlsen AN (2014): The Time Course of Corticospinal Excitability during a Simple Reaction Time Task, PLoS ONE 9(11): e113563. doi:10.1371/journal.pone.0113563. Available at:

http://journals.plos.org/plosone/article?id=10.1371/journal.pone.0113563)

17.

Mageed, Resan Kahribt(1997): Applications in physiology and sports training, Shorook House, Cairo. (In Arabic language)

18.

Mageed, Resan Kahribt, and Omar, Mohammed Sabri(2001): Analysis of the mechanical differences between traditional and grab starts in the swimming competitions, Encyclopedia of Physical Education researches in Academic Arab world, Curricula House, Amman. (In Arabic language)

19.

Maglischo, E.W (1993): Swimming even Faster, May Field publishing Company California.

20.

Maglischo. EW (2003): Swimming Fastest , Edwards Brothers , United States of America

21.

Mokhtar, HanafiMahmoud(1990): Scientific basis in football training, Arab Thought House, Cairo. (In Arabic language)

22.

Thanopoulos V, Rozi G, Okičić T, Dopsaj M, Jorgić B, Madić D, Veličković S, Milanović Z, Spanou F, Batis E (2012): Differences in the Efficiency Between the Grab and Track Starts for Both Genders in Greek Young Swimmers , Journal of Human Kinetics;May2012, Vol. 32, pp43-51. Available at:

http://www.ncbi.nlm.nih.gov/pmc/articles/PMC3590859/ 